\title{
In vivo glioblastoma growth is reduced by apyrase activity in a rat glioma model
}

\author{
Fernanda B Morrone ${ }^{1,4}$, Diogo L Oliveira1 ${ }^{1}$ Patrícia Gamermann ${ }^{1}$, \\ Joseli Stella1 ${ }^{1}$ Suzana Wofchuk ${ }^{1}$, Márcia R Wink ${ }^{2}$, Luise Meurer ${ }^{3}$, Maria Isabel \\ A Edelweiss $^{3}$, Guido Lenz ${ }^{2}$ and Ana Maria O Battastini*1
}

\author{
Address: ${ }^{1}$ Departamento de Bioquímica, ICBS, UFRGS, Porto Alegre, RS, Brazil, ${ }^{2}$ Departamento de Biofísica IB, UFRGS, Porto Alegre, RS, Brazil \\ ${ }^{3}$ Departamento de Patologia, HCPA, UFRGS, Porto Alegre, RS, Brazil and ${ }^{4}$ Faculdade de Farmácia, PUCRS, Porto Alegre, RS, Brazil \\ Email: Fernanda B Morrone - fmorrone@portoweb.com.br; Diogo L Oliveira - losh@ufrgs.br; \\ Patrícia Gamermann - patigamermann@hotmail.com; Joseli Stella - joselistella@redemeta.com.br; Suzana Wofchuk - swofchuk@ufrgs.br; \\ Márcia R Wink - marciawink@yahoo.com.br; Luise Meurer - lmeurer@terra.com.br; Maria Isabel A Edelweiss - mie@edelweiss.com.br; \\ Guido Lenz - lenz@ufrgs.br; Ana Maria O Battastini* - abattastini@terra.com.br \\ * Corresponding author
}

Published: 23 September 2006

BMC Cancer 2006, 6:226 doi:10.1 I86/147/-2407-6-226

This article is available from: http://www.biomedcentral.com/I47I-2407/6/226

(c) 2006 Morrone et al; licensee BioMed Central Ltd.

This is an Open Access article distributed under the terms of the Creative Commons Attribution License (http://creativecommons.org/licenses/by/2.0), which permits unrestricted use, distribution, and reproduction in any medium, provided the original work is properly cited.
Received: 25 April 2006

Accepted: 23 September 2006

\begin{abstract}
Background: ATP is an important signalling molecule in the peripheral and central nervous system. Both glioma growth and tumor resection induces cell death, thus liberating nucleotides to the extracellular medium. Nucleotides are hydrolyzed very slowly by gliomas when compared with astrocytes and induce neuronal cell death and glioma proliferation. The objective of the present study was to test the involvement of extracellular ATP in glioblastoma growth in a rat glioma model.
\end{abstract}

Methods: To deplete the extracellular ATP, the enzyme apyrase was tested on the treatment of gliomas implanted in the rats CNS. One million glioma C6 cells in 3 microliters of DMEM/FCS were injected in the right striata of male Wistar rats, 250-270 g. After 20 days, the rats were decapitated and the brain sectioning and stained with hematoxylin and eosine. We performed immunohistochemical experiments with Ki67, CD3I and VEGF. Total RNA was isolated from cultured glioma C6 cells and the CDNA was analyzed by Real Time-PCR with primers for the NTPDase family.

Results: C6 glioma cells effectively have a low expression of all NTPDases investigated, in comparison with normal astrocytes. The implanted glioma co-injected with apyrase had a significant reduction in the tumor size $(p<0.05)$ when compared with the rats injected only with gliomas or with gliomas plus inactivated apyrase. According to the pathological analysis, the malignant gliomas induced by $\mathrm{C} 6$ injection and co-injected with apyrase presented a significant reduction in the mitotic index and other histological characteristics that indicate a less invasive/proliferative tumor. Reduction of proliferation induced by apyrase co-injection was confirmed by counting the percentage of Ki67 positive glioma cell nuclei. According to counts with CD3I, vessel density and neoformation was higher in the $\mathrm{C} 6$ group 20 days after implantation. Confirming this observation, rats treated with apyrase presented less VEGF staining in comparison to the control group.

Conclusion: These results indicate that the participation of extracellular ATP and the ecto-nucleotidases may be associated with the development of this type of brain tumor in an in vivo glioma model. 


\section{Background}

Gliomas are a type of primary brain tumor that display an extensive invasive behavior, but do not metastasize. The growth and invasiveness into the surrounding normal brain tissue makes gliomas a major challenge for clinical intervention [1-3]. Therefore, the elucidation of the mechanisms involved in tumor growth, invasion and angiogenesis could aid in the treatment of these tumors.

The invasive cellular behavior of malignant gliomas is determined by receptor mediated cell-substratum contacts and cell-cell interaction, as well as cellular locomotion [4]. Clues to the invasion process have been ascertained through clarification of the key roles played by the extracellular matrix (ECM), cell-adhesion molecules and matrix degrading proteases [5].

Among other elements, vascular endothelial growth factor (VEGF) is one of the most prominent angiogenic growth factors. In fact, it has been shown that VEGF is secreted by the $\mathrm{C} 6$ rat glioma cell line [6]. This growth factor is produced by almost all solid tumors and its receptors are highly expressed on vascular endothelial cells and, predominantly, in vessels in the proximity of the tumor [7]. Moreover, some other systems may be involved in the growth and invasion of the gliomas. Glutamate secreting glioma cells demonstrate a growth advantage and glioma cells release excitotoxic concentrations of glutamate, thus killing neurons close to the tumor border and opening space for tumor growth [8-10].

Another important signalling molecule that may be involved in glioma development is ATP $[11,12]$. In glioma C6 cells, ATP can bind and activate P2Y2, whereas its degradation product, ADP, activate P2Y1 and P2Y12 receptors [13-16].

In previous studies, we showed the involvement of the purinergic system in glioma proliferation in different cell types [17] and that glioma cells present a clear resistance to death induced by cytotoxic concentrations of ATP when compared with normal brain tissue [18]. Taken together with its inability to metabolize extracellular ATP [19], the purinergic system may form part of a novel and important mechanism associated with the malignance of these tumors.

ATP may be liberated into the extracellular space by the excitotoxic death of the normal host cells and by the injury caused by tumor resection, which is the mainstay of initial therapy for gliomas [20]. We hypothesize that ATP liberated under these conditions may, besides inducing proliferation of the glioma itself, induce the cell death of normal tissue and, consequently, increase the interstitial space around the malignant glioma.
To test this hypothesis, we examined the effect of co-injection of apyrase, an ATP depleting enzyme, in a C6 rat glioma experimental model, which has been extensively used to test antitumoral interventions.

\section{Methods \\ Cell culture}

The C6 rat glioma cell line was obtained from the American Type Culture Collection (Rockville, Maryland, U.S.A.). Cells were grown in culture flasks in Dulbecco's Modified Eagle's medium (DMEM) with 5\% fetal calf serum (FCS) (Cultilab, Brazil).

\section{Glioma implantation}

Rat C6 glioma cells at around $70 \%$ confluency were trypsinized, washed once in DMEM/5\% FCS, spun down and ressuspended in the same medium. A total of one million cells in a volume of $3 \mu \mathrm{l}$ were injected at a depth of $6.0 \mathrm{~mm}$ in the right striata (coordinates with regard to bregma: $0.5 \mathrm{~mm}$ posterior and $3.0 \mathrm{~mm}$ lateral) of anesthetized male Wistar rats, 250-270 g [9]. After 20 days, the rats were decapitated and the entire brain was removed, sectioned and fixed with 10\% paraformaldehyde.

All the procedures were approved by the Ethical Committee of the Hospital de Clinicas de Porto Alegre.

\section{Treatment with temozolomide}

Ten days post-implantation, the rats were treated with 5 $\mathrm{mg} / \mathrm{Kg} /$ day (i.p.) of temozolomide or DMSO (control group of temozolomide) during 5 consecutive days. The drug was dissolved in DMSO at a final concentration of $10 \%[21]$.

\section{Co-injection of apyrase with $\mathrm{C} 6$ cells}

Just before the injection, an apyrase (VII grade) (Sigma Chemical Co., St. Louis, MO, USA) solution containing 2 $\mathrm{U} / \mathrm{ml}$ was prepared in a 66 cell suspension in DMEM/FCS. Cell viability was evaluated by trypan blue exclusion and MTT assays. This preparation, containing C6 cells and apyrase, was injected in $3 \mu \mathrm{l}$. An additional pulse of $3 \mu \mathrm{l}$ DMEM/FCS with apyrase was given within $1 \mathrm{~min}$ of the first injection. As a control group, apyrase was denatured by boiling for five minutes and was then injected together with a C6 cell suspension using the same protocol described above.

The enzyme activity of the injected apyrase was controlled by measuring the hydrolysis of ATP and ADP in an incubation medium containing $50 \mathrm{mM}$ Tris. $\mathrm{HCl}, \mathrm{pH} 7.5$ and $1.5 \mathrm{mM} \mathrm{CaCl}_{2}$ and ATP or ADP as substrates to a final concentration of $1 \mathrm{mM}$, at $37^{\circ} \mathrm{C}$. The reaction was stopped by the addition of $0.2 \mathrm{ml}$ of $10 \%$ TCA. The amount of inorganic phosphate liberated was measured by the malachite green method [22]. 


\section{Pathological analysis and tumor volume quantification} At least three hematoxylin and eosin (H\&E) sections (4 $\mu \mathrm{m}$ thick, paraffin embedded) of each tumor were analyzed by two independent pathologists, blinded for the experimental data. For tumor size quantification, images were captured using a digital camera connected to the microscope and analyzed using Image Tool Software ${ }^{\mathrm{TM}}$. The total volume $\left(\mathrm{mm}^{3}\right)$ of the tumor was computed by summing the segmented areas and by the multiplication of the slice resolution.

\section{Immunohistochemical staining}

Paraffin embedded, 5-mm formalin fixed tissue sections were mounted on microscope slides. Tissue sections were then dried overnight at $60^{\circ} \mathrm{C}$, dewaxed in xylene and rehydrated with distilled water. Endogenous peroxidase was inhibited by $1 \% \mathrm{H}_{2} \mathrm{O}_{2}$ in methanol for $10 \mathrm{~min}$. Incubation with the following antibodies was performed overnight at room temperature: anti-Ki67 (1:20) (Dako, USA) and anti-VEGF (1:400) (Dako, USA), followed by incubation with secondary antibody and Streptavidin-AvidinBiotin (Kit Lsab, Dako, USA). The peroxidase reaction was performed using 3,3'diaminobenzidine tetrahydrochloride (DAB), according to the manufacturer's specifications. Finally, sections were counterstained with Harris haematoxylin. Glioma cell proliferation was assessed by counting the percentage of Ki67 positive glioma cell nuclei in five independent high-magnification $(\times 200)$ fields per animal. Sections of rat spleen were used as positive controls.

To evaluate microvessel density, we used anti-CD31 mAb (BD PharMingen, USA). The glioma sample specimens were snap frozen in liquid nitrogen and cut into $4 \mu \mathrm{m} \mathrm{sec}-$ tions. Frozen tissue was fixed in cold acetone $\left(-20^{\circ} \mathrm{C}\right)$. Subsequently, serial sections were stained with anti-CD31 mAb (1:30). The reaction was developed as described above. The number of positive vessels/microscopic field $(\times 200)$ was counted. All samples were read blindly by two independent readers, and the mean of their scores is presented.

\section{Real time PCR analysis}

Total RNA from cortical rat astrocytes or C6 glioma cells was isolated from confluent cultures with RNA Mini Kit (Qiagen) in accordance with the manufacturer's instructions. The cDNA species were synthesized with SuperScript II (Life Technologies) from $5 \mu \mathrm{g}$ of total RNA in a total volume of $20 \mu \mathrm{l}$ with both oligo (dT) primer and random hexamers in accordance with the manufacturer's instructions. SYRB Green I-based real-time PCR was carried out using the $M J$ Research DNA Engine OpticonTM Continuous Fluorescence Detection System (MJ Research Inc., Walthan, MA), as described previously [23]. All PCR mixtures contained: PCR buffer (final concentration: 10
$\mathrm{mM}$ Tris- $\mathrm{HCl}(\mathrm{pH} 9.0), 50 \mathrm{mM} \mathrm{KCl}, 2 \mathrm{mM} \mathrm{MgCl}_{2}$, and $0.1 \%$ Triton X-100), $250 \mu \mathrm{M}$ deoxy-NTP (Roche), $0.5 \mu \mathrm{M}$ of each PCR primer, $0.5 \times$ SYBR Green I (Molecular Probes), 5\% DMSO, and $1 \mathrm{U}$ taq DNA polymerase (Promega, Madison, WI) with $2 \mu \mathrm{l}$ cDNA in a $25 \mu \mathrm{l}$ final volume reaction mix. The samples were loaded into wells of Low Profile 96-well microplates. After an initial denaturation step for $1 \mathrm{~min}$ at $94^{\circ} \mathrm{C}$, conditions for cycling were 35 cycles of $30 \mathrm{sec}$ at $94^{\circ} \mathrm{C}, 30 \mathrm{sec}$ at $56^{\circ} \mathrm{C}, 1 \mathrm{~min}$ at $72^{\circ} \mathrm{C}$. The fluorescence signal was measured right after incubation for $5 \mathrm{sec}$ at $79^{\circ} \mathrm{C}$ following the extension step, which eliminates possible primer dimer detection. At the end of the PCR cycles, a melting curve was generated to identify specificity of the PCR product. For each run, serial dilutions of human GAPDH plasmids were used as standards for quantitative measurement of the amount of amplified DNA. In addition, for normalization of each sample, hGAPDH primers were used to measure the amount of hGAPDH cDNA. All samples were run in triplicate and the data were presented as a ratio of enzymes/ GAPDH. The set of primers used for NTPDase1 (CD39), NTPDase2 (CD39L1), NTPDase3 (CD39L3), NTPDase5 (CD39L4) and NTPDase6 (CD39L2) were as described in Vollmayer et al. (2001) [24]. Oligonucleotides were obtained from Invitrogen. Negative controls were performed with water as template and positive controls were plasmids with cDNA sequences for mouse NTPDase1, rat NTPDase2, and human NTPDase3, NTPDase5 and NTPDase6.

\section{Statistical analysis}

Data were analyzed by one-way analysis of variance ANOVA, followed by Tukey-Kramer test. $P$ values $<0.05$ were taken to indicate statistical significance and means \pm SEM are presented.

\section{Results}

In the present study we tested the effect of the apyrase enzyme on the growth of glioma cells in vivo. We have previously shown that $\mathrm{C} 6$ gliomas, a cell line that was originated from $\mathrm{N}$-nitrosomethylurea-treated rats, exhibited almost undetectable ATP and ADP-degrading activity; however, our results did not allow the identification of which NTPDase family members are expressed by these cells [19]. To investigate which of the ecto-NTPDases are present in the C6 glioma cell line, total RNA was isolated from cultured glioma cells and the cDNA was analyzed by Real Time-PCR with primers for the NTPDase family. Figure 1 shows that $\mathrm{C} 6$ cells effectively have a low expression of all NTPDases investigated, in comparison with normal astrocytes. We, therefore, chose the purified apyrase, which hydrolyzes ATP and ADP at a similar rate to test our hypothesis of the ATP participation in the process of glioma invasion in host brain. 


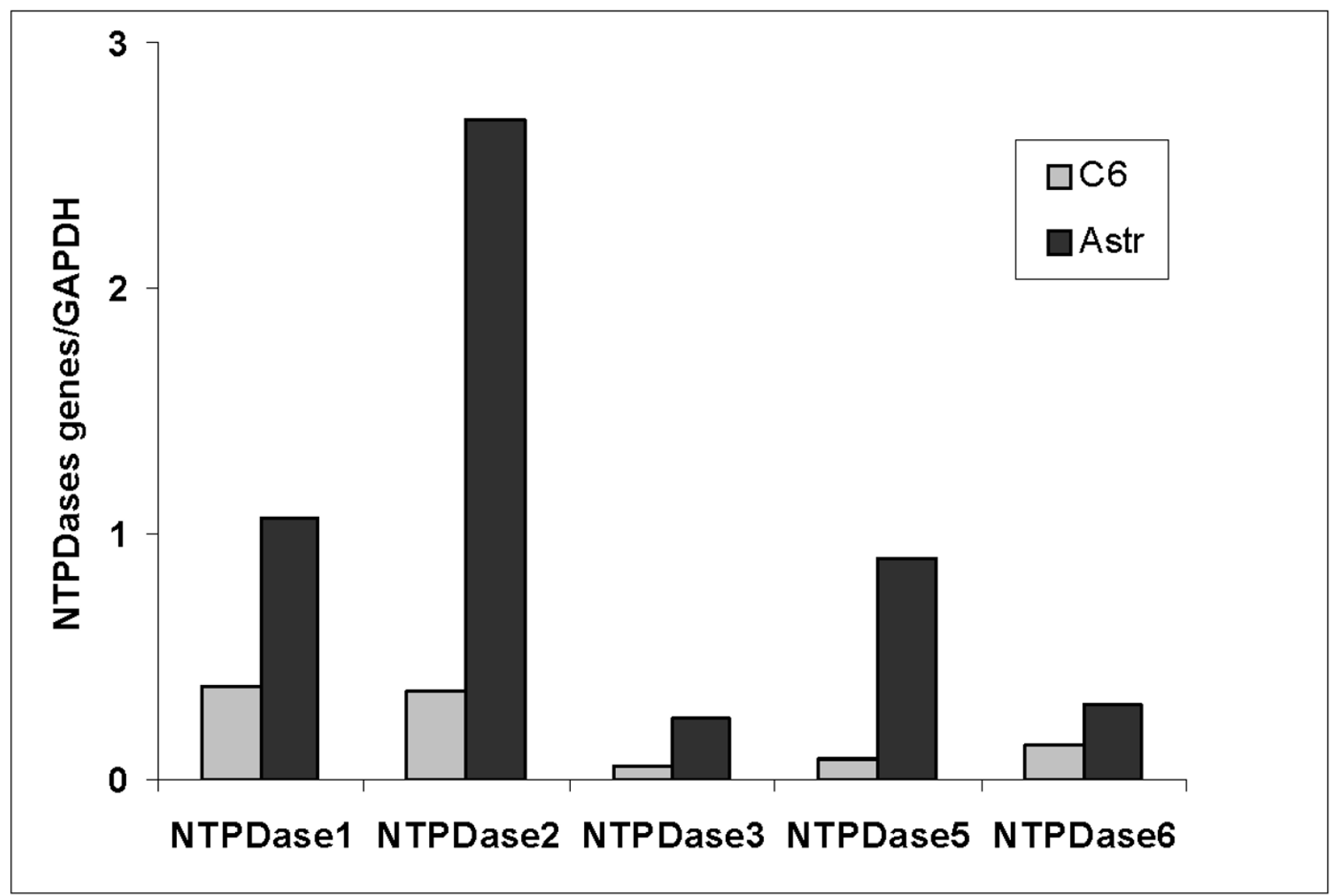

Figure I

Comparison of NTPDase family expression in rat cortical astrocytes and rat C6 gliomas by quantitative real-time RT-PCR analysis. The expression of NTPDase members in astrocytes and C6 gliomas was quantitatively analyzed by real-time PCR as described in material and methods. C6: rat glioma cell line. Astr: cortical rat astrocytes. The results are presented as a ratio of cDNA enzymes/GAPDH.

The implanted tumors have characteristics that are closer to those of human glioblastomas with the C6 cells growing in the intracerebral, intraventricular and intraparenchymal spaces (data not shown). Haematoxylin and eosin examination showed that the implanted tumor has a high mitotic index, nuclear pleomorphism, foci of tumor necrosis, intratumoral hemorrhage and parenchymal invasion (Table 1). In some cases, pathological analysis identified pallisading cells delineating the foci of necrosis and lymphocytic infiltration, with the occasional formation of edema fluid and neovascularization, which are characteristics of glioblastoma multiforme in humans (Table 1) (Fig. 3a and 3c).

In order to analyze whether the tumors implanted into host brain were responsive to drugs that are clinically used to treat gliomas and to validate our model, the rats were treated with the alkylating agent, temozolomide [25]. In
Table I: Characteristics of implanted gliomas.

\begin{tabular}{ccc}
\hline & Glioma (n = 9) & $\begin{array}{c}\text { Glioma + } \\
\text { Apyrase }(\mathbf{n}=\mathbf{8})\end{array}$ \\
\hline Coagulative necrosis & $5 / 9$ & $0 / 8$ \\
Intratumoral Hemorrhage & $2 / 9$ & $1 / 8$ \\
Lymphocytic infiltration & $8 / 9$ & $5 / 8$ \\
Peritumoral edema & $5 / 9$ & $1 / 8$ \\
Peripheric pseudopalisading & $3 / 9$ & $0 / 8$ \\
Mitotic index: mitosis/HPF & $14.5 \pm 4.7$ & $8.4 \pm 2.9 *$
\end{tabular}

The histological variables (coagulative necrosis, intratumoral hemorrhage, lymphocytic infiltration, peritumoral edema, peripheric pseudopalisading) were regarded as present or absent. Mitosis was counted in ten high power fields (HPF) of the periphery of the lesion, and the average of this counting was used as mitotic index. $* P<0.05$, Students $t$-Test. 

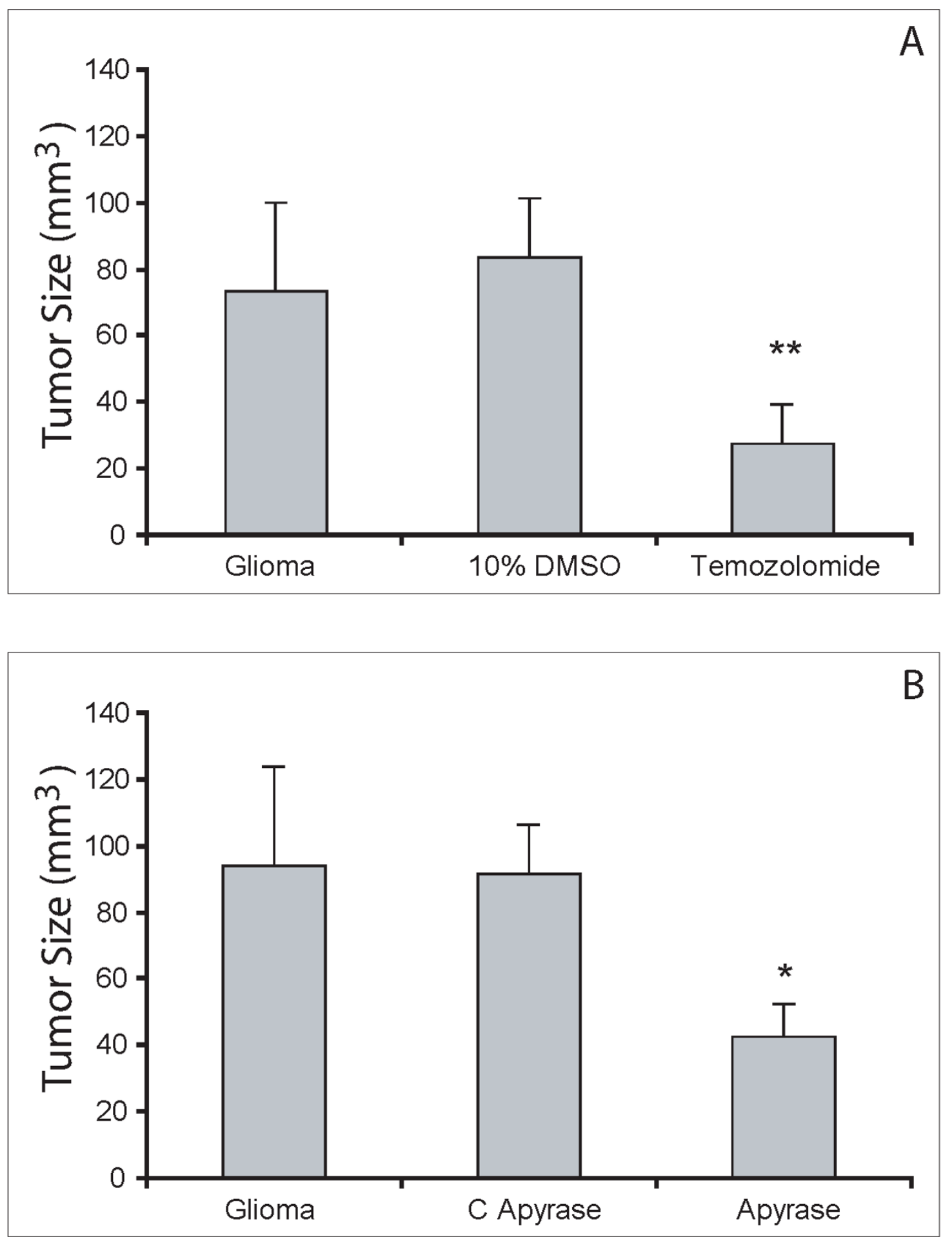

\section{Figure 2}

Tumor size of implanted gliomas. Tumor size was measured $20 \mathrm{~d}$ after implantation of $\mathrm{C} 6$ cells in the different groups. (A) Rats were treated with $10 \%$ DMSO (vehicle control) or temozolomide in 10\% DMSO $(n=5)$. (B) C6 cells were co-injected with: denaturated apyrase ( $C$ apyrase) or $2 U$ of apyrase (apyrase group) $(n=6)$. Data are means $\pm S E M$. **p $<0.01$; $*_{p}<0.05$ for comparison versus control, as determined by ANOVA, followed by Tukey-Krammer test. 


\section{GLIOMA}
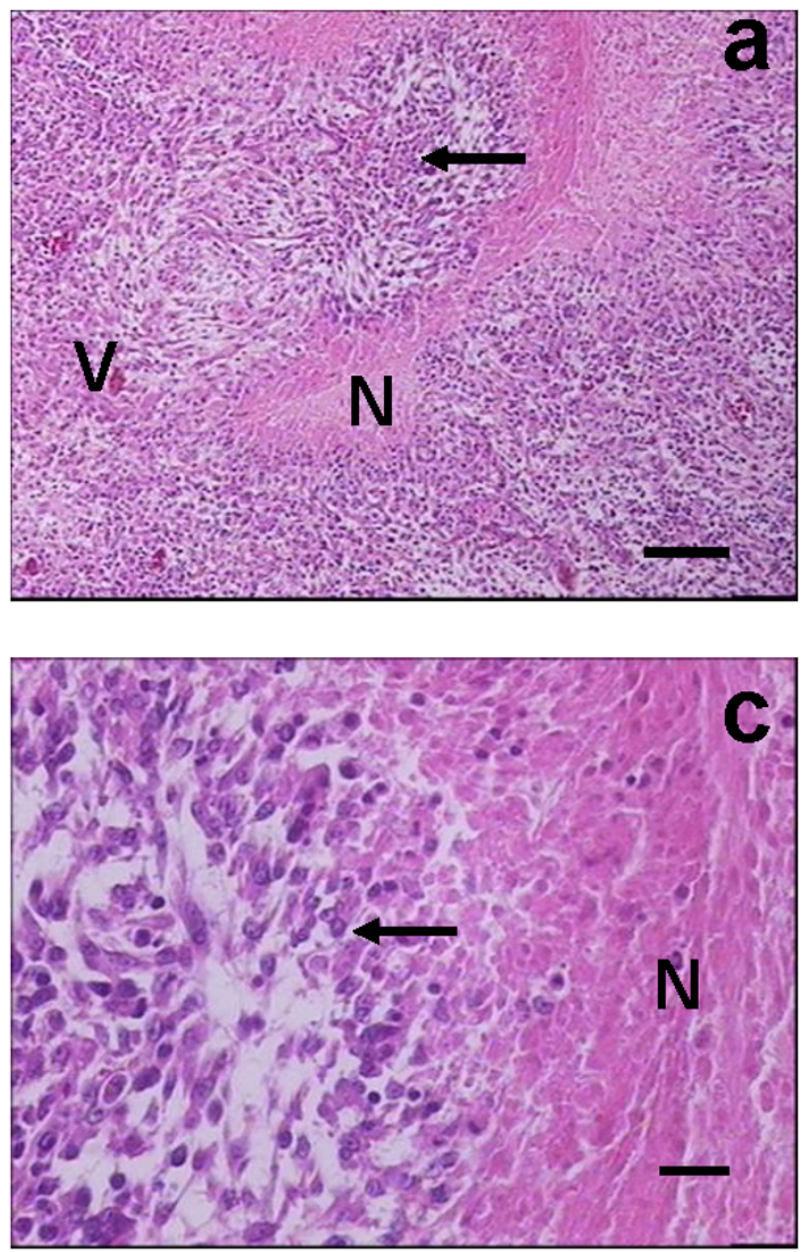

GLIOMA + APYRASE
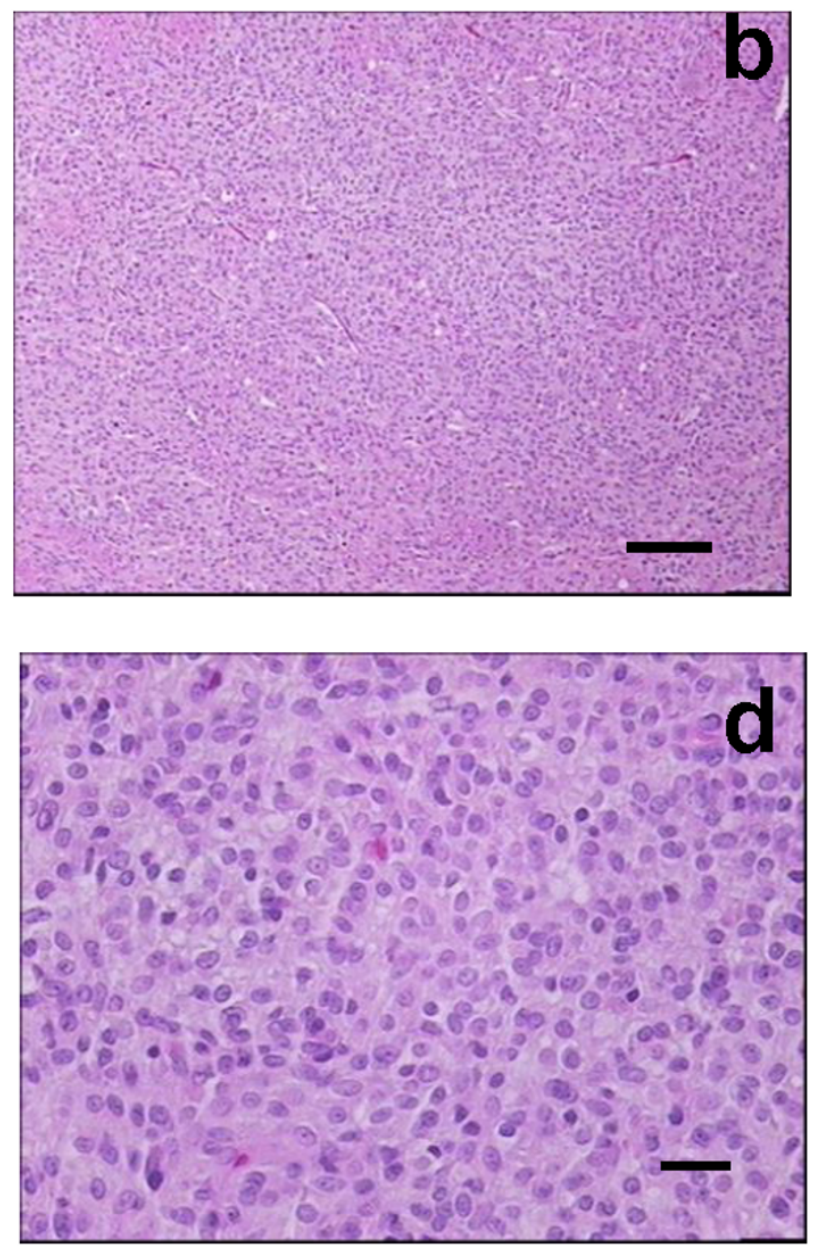

\section{Figure 3}

The sections of implanted rat glioma were stained with haematoxylin and eosin $(\mathrm{H} \& \mathrm{E})$. Histological characteristics that define glioblastoma multiform as seen in rats implanted with gliomas $(a, c)$ and in rats co-injected with apyrase $(b, d)$. Necrosis $(\mathrm{N})$ and microvascular proliferation (V), giant cell formation and nuclear pleomorphism (arrow). Scale bars $=100 \mu \mathrm{m}(\mathrm{a}, \mathrm{b}) ; 20 \mu \mathrm{m}(\mathrm{c}, \mathrm{d})$.

fact, tumor size analysis showed that the rats treated with temozolomide presented a significant reduction in tumor size when compared with the control groups (Fig. 2a). In addition, rats treated with temozolomide survive significantly longer than their respective controls, demonstrating a relative benefit of $100 \%$ in the rats' survival, that means, at the time that $100 \%$ of control animals died all animals from the treated group were still alive (data not shown).

Confirming our purinergic hypothesis of glioma growth, the results presented in Figure $2 \mathrm{~b}$ show that the rats with implanted glioma co-injected with apyrase had a significant reduction in the tumor size $(\mathrm{p}<0.05)$ in comparison with the rats injected only with gliomas or with gliomas plus inactivated apyrase, indicating that it is not the presence of the polypeptide, but the enzymatic activity that is responsible for the effect of apyrase. The effect of apyrase (2 U apyrase $/ 10^{6}$ cells) on C6 cell proliferation in culture showed that the enzyme was not toxic to the cells but instead, induced an increase by around $40 \%$ of the cell number after $24 \mathrm{~h}$ of treatment. Additionally, the C6 cells were detached from the surface handled exactly as for the injection (with or without apyrase) and were subsequently re-plated in DMEM/FCS for 24 and 48 h. Cell viability was analyzed by trypan blue exclusion and MTT assays immediately after the cell preparation for injection and after 24 and $48 \mathrm{~h}$ of culture. The cells presented more than $90 \%$ viability when compared to the control cells in all conditions tested, indicating that the effect of apyrase 
GLIOMA
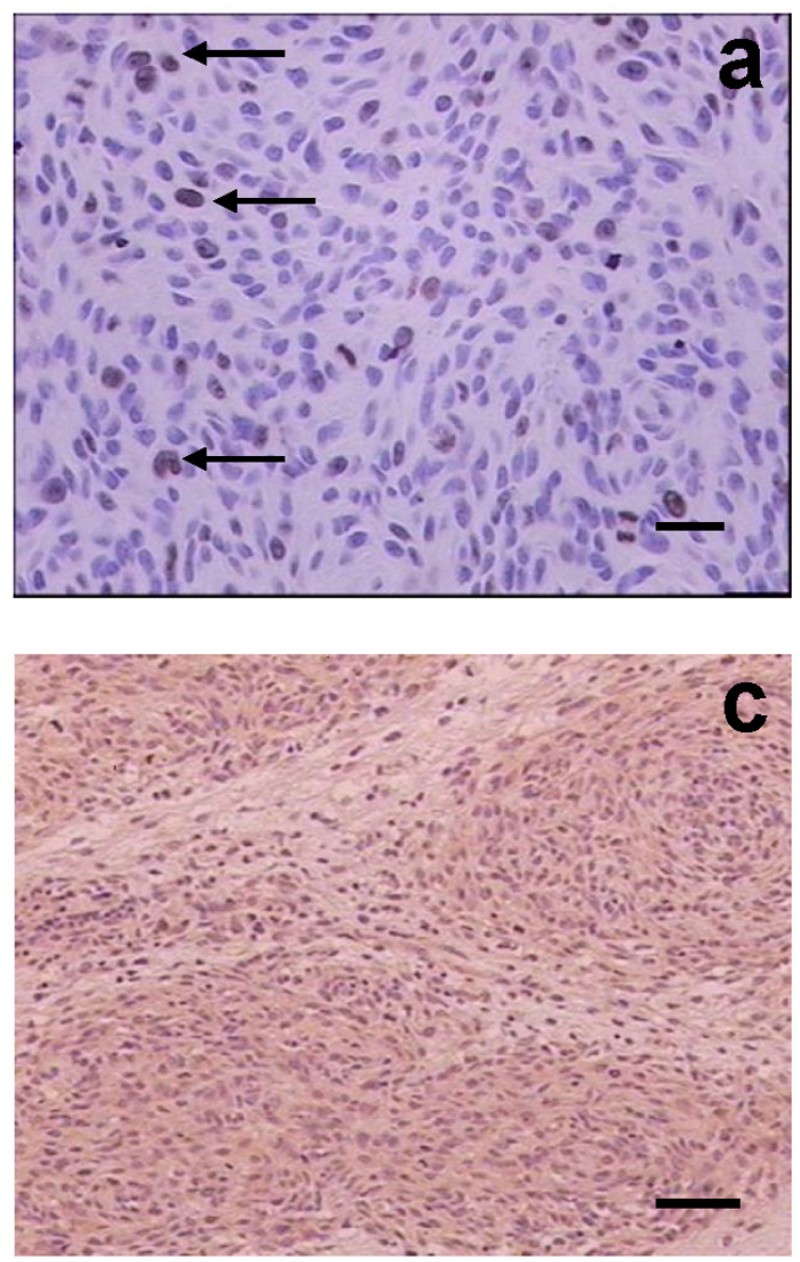

GLIOMA + APYRASE
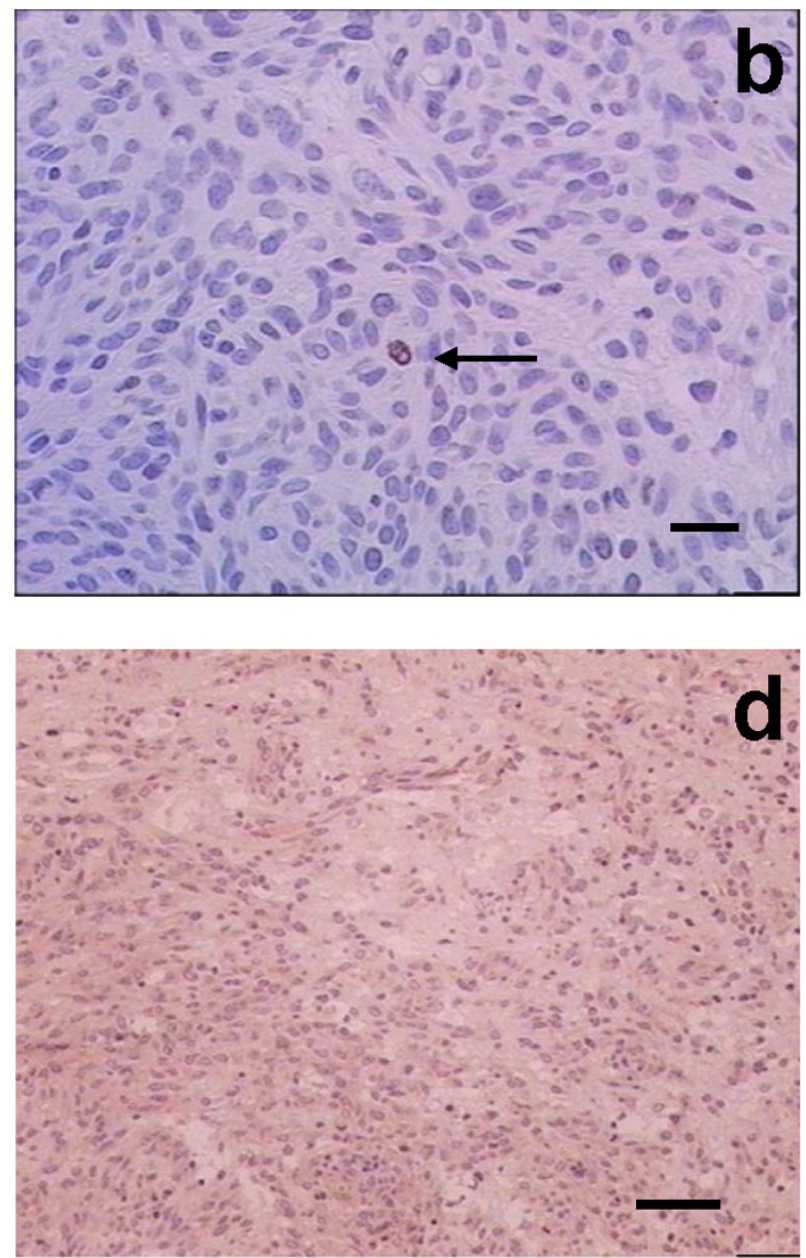

\section{Figure 4}

Immunohistochemical stainings of gliomas. Glioma cell proliferation was assessed by immunostaining for Ki67 positive glioma cell nuclei (arrows) in rats implanted with gliomas (a) and in rats co-injected with apyrase (b). The sections were immunostained for VEGF, in rats implanted with gliomas (c) and in rats co-injected with apyrase (d). Scale bars $=20 \mu \mathrm{m}(\mathrm{a}, \mathrm{b}) ; \mathrm{I} 00 \mu \mathrm{m}$ (c,d).

is not probably on the initial viability of the injected cells but rather on the subsequent tumor implantation and growth.

According to the pathological analysis, the malignant gliomas induced by C6 injection and co-injected with apyrase presented a significant reduction in the mitotic index and other histological characteristics that indicate a less invasive/proliferative tumor (Table 1). Less lymphocytic infiltration and peritumoral edema were observed as well as the absence of pseudopalisading necrosis (Fig. 4b and $4 d)$. Reduction of proliferation induced by apyrase co- injection was confirmed by counting the percentage of Ki67 positive glioma cell nuclei (Table 2) (Fig. 4a and 4b).

Since tumor growth is dependent on the ability to induce angiogenesis, we performed immunohistochemical experiments with CD31. According to counts with CD31, vessel density and neoformation was higher in the C6 group 20 days after implantation, in comparison with the group co-injected with apyrase (Table 2 ). Confirming this observation, the implanted gliomas with apyrase presented less VEGF staining in comparison to the control group (glioma alone) (Fig. 4c and $4 \mathrm{~d}$ ). 
Table 2: Immunohistochemical analysis of Ki67 and CD3 I in rats implanted glioma.

\begin{tabular}{ccc}
\hline & Glioma & Glioma + Apyrase \\
\hline $\mathrm{Ki67} \mathrm{\#}(\mathrm{n}=5)$ & $48.7 \pm 2.3$ & $11.6 \pm 7.9 * *$ \\
$\mathrm{CD} 3 \mathrm{(}(\mathrm{n}=2)$ & $96 \pm 22.6$ & $37.5 \pm 3.5$
\end{tabular}

\# percentage of positive cells. Data are the means \pm SEM

$\checkmark$ Data are the means \pm SEM for the number of vessels

$*^{* *} \mathrm{p}<0.01$, Students $t$-test.

\section{Discussion}

In the present study, we investigated the effect of the coinjection of the enzyme apyrase with implanted $\mathrm{C} 6$ gliomas cells. It is well known that in vitro assays for growth and invasion only represent isolated aspects of the multicascade process of the in vivo tumor growth [4]. For this reason, we decided to use an in vivo glioma model that, despite its limitations, is useful for the study of growth, angiogenesis and invasion of gliomas [3].

Extracellular ATP could be hydrolyzed by the action of a cascade of enzymes, which includes the family of E-NTPDases: NTPDase1 (CD39), NTPDase2 (CD39L1), NTPDase3 (CD39L3), NTPDase5 (CD39L4) and NTPDase6 (CD39L2) [26] and the more recently described NTPDase7 and NTPDase8 [26-28]. Some of these enzymes have been related with different tumors [29-31] and recent studies demonstrated that NTPDase5 (CD39L4) is a proto-oncogene PCPH, which is involved in tumor growth [32]. According to our results, the C6 cells present a very low expression of the NTPDase1 (CD39), NTPDase2 (CD39L1) and NTPDase3, the three main enzymes involved in the cell surface ATP degradation when compared to astrocytes. Previous studies showed that nucleotides and nucleosides induce proliferation in glioma cell lines [17] while ATP can mediate death in dissociated primary cerebellar granules or striatal neurons and in hippocampal organotypic cultures [33]. The indirect autocrine nature of this process should be noted. The tumor induces, through the death of normal cells, the release of more ATP that stimulates its own multiplication and, as a consequence, the cell death of other cells opening space to be occupied by tumor cells and liberating more ATP to continue the invasive process. Thus we hypothesize that the re-establishment of NTPDase activity may reduce glioma growth.

Purified apyrase is an enzyme widely used to deplete ATP and hydrolyzes ATP and ADP at the same rate as NTPDase1 [34]. Therefore, the apyrase may regulate the extracellular nucleotide concentration and, thus, modu- late their biological effects when activated by P2Y and P2X receptors.

Our experiments demonstrate that the co-injection of apyrase significantly diminished the growth of implanted gliomas in rats after twenty days of tumor induction. Considering that the injection of apyrase was done only at the moment of implantation, the effect of ATP depletion is probably at the implantation and initial growth of the glioma. This could be of therapeutic interest, since the application of apyrase in the surgical resection cavity could be helpful in reducing the initial growth of invaded tumor.

In addition to the reduction in the glioma size, pathological analysis demonstrated the lack of some important malignant characteristics, typical of the glioblastomas, in the tumors co-injected with apyrase (Table 1). Among these, of note is the reduction of the mitotic index in the rats treated with apyrase, indicating that ATP has an important role in glioma proliferation in vivo. The participation of ADP in this process should not be excluded since this nucleotide can bind to P2 receptors and is potentially hydrolyzed by the injected apyrase.

As mentioned above, angiogenesis is an extremely important process for sustained tumor growth. Studies have demonstrated that $\mathrm{C} 6$ and human glioma cell lines secrete VEGF $[6,35,36]$. Since invasive properties are largely dependent on the presence of new vessels, CD31 was studied and demonstrated a greater staining in the samples from rats implanted with the $\mathrm{C} 6$ cells in relation to those co-injected with apyrase (Table 2). This result was confirmed by the stronger VEGF staining in rats implanted with glioma, when compared with the apyrase group (Fig. $4 \mathrm{c}$ and $4 \mathrm{~d}$ ). These results clearly indicate that microvascular proliferation is decreased in tumors treated with apyrase in relation to the control group, with a consequent decrease in the blood flow in tumor areas with high cell proliferation. The insufficient vascular supply may become the limiting factor for tumor growth [7].

\section{Conclusion}

In conclusion, the data presented herein clearly show that the presence of an ATP-depleting enzyme at the moment of glioma implantation causes a significant decrease in the growth, angiogenesis and proliferation index. The exact mechanisms to explain these observations remain under evaluation, however, the participation of ATP and the ecto-nucleotidases may be associated with the development of this type of brain tumor in an in vivo glioma model. 


\section{Abbreviations}

CNS, central nervous system; DAB, 3,3'diaminobenzidine tetrahydrochloride; DMEM, dulbecco's modified eagle's medium; DMSO, dimethyl sulfoxide; ECM, extracellular matrix; FCS, fetal calf serum; H\&E, hematoxylin and eosin; VEGF, vascular endothelial growth factor.

\section{Competing interests}

The author(s) declare that they have no competing interests.

\section{Authors' contributions}

FBM performed cell growth, glioma injection, drug treatments, conducted $\mathrm{H} \& \mathrm{E}$ and immunohistochemical analysis of gliomas, was responsible for data analysis and drafting of the manuscript. DLO participated in the glioma injection. PWG performed drug treatments and tumor size measurements. JS performed cell growth. SW participated in the glioma injection and glutamate uptake assay. MRW carried out Real Time PCR studies. LM and MIAE conducted H\&E and immunohistochemical analysis of gliomas. GL participated in the study design and drafting of the manuscript. AMOB conceived of the study, participated in its design, coordination and in the draft of the manuscript. All authors read and approved the final manuscript.

\section{Acknowledgements}

We thank Dr. Matilde Achaval, Dr. Carmen Gottfried, Neiva Copetti and Jorge A Lopes for their experimental assistance. We are also grateful to Dr. Simon C. Robson and to Biogen from Brazil for the gift of the Ki67 and CD3I antibodies. This work was supported by grants from the Brazilian agencies: Conselho de Desenvolvimento Científico e Tecnológico (CNPqBrasil), Fundação de Amparo a Pesquisa do Rio Grande do Sul (FAPERGS) and Fundo de Incentivo à Pesquisa e Eventos (HCPA).

\section{References}

I. Laws ER, Shaffrey ME Jr: The inherent invasiveness of cerebral gliomas: implications for clinical management. Int J Neurosci 1999, I 7:413-420.

2. Holland EC: Gliomagenesis: genetic alterations and mouse models. Nature 2001, 2:120-129.

3. Grobben B, De Deyn PP, Slegers H: Rat C6 glioma as experimental model system for the study of glioblastoma growth and invasion. Cell Tissue Res 2002, 310(3):257-70.

4. Kaczarek E, Zapf S, Bouterfa H, Tonn JRC, Westphal M, Giese A: Dissecting glioma invasion: interrelation of adhesion, migration and intercellular contacts determine the invasive phenotype. Int J Devl Neur 1999, 17:625-64I.

5. Chintala SK, Tonn JC, Rao JS: Matrix metalloproteinases and their biological function in human gliomas. Int J Devl Neur 1999, 17:495-502.

6. Plate KH, Millauer B, Ullrich A, Risau W: Up-regulation of vascular endothelial growth factor and its cognate receptors in a rat glioma model of tumor angiogenesis. Cancer Res 1993, 53:5822-5827.

7. Schaper W, Buschmann I: VEGF and therapeutic opportunities in cardiovascular diseases. Cur Op Biotec 1999, 10:54I-543.

8. Ye ZC, Sontheimer H: Glioma cells release excitotoxic concentrations of glutamate. Cancer Res 1999, 59:4383-4391.

9. Takano T, Lin JHC, Arcuino G, Gao Q, Yang J, Nedergaard M: Glutamate release promotes growth of malignant gliomas. Nature Med 200I, 7:1010-1015.
10. Eyupoglu IY, Hahnen E, Heckel A, Siebzehnrubl FA, Buslei R, Fahlbusch $R$, Blumcke I: Malignant glioma-induced neuronal cell death in an organotypic glioma invasion model. J Neurosurg 2005, 102(4):738-44.

II. Ralevic V, Burnstock G: Receptors for purines and pyrimidines. Pharmacol Rev 1998, 50:413-492.

12. White N, Burnstock G: $\mathbf{P 2}$ receptors and cancer. Trends Pharmacol Sci 2006, 27(4):21I-217.

13. Sabala P, Czajkowski R, Przybylek K, Kalita K, Kaczmarek L, Baranska J: Two subtypes of $\mathbf{G}$ protein-coupled nucleotide receptors, P2Y(I) and P2Y(2) are involved in calcium signalling in glioma C6 cells. Br J Pharmacol 200I, I 32(2):393-402.

14. Czajkowski R, Baranska J: Cross talk between the ATP and ADP nucleotide receptor signalling pathways in glioma $C_{6}$ cells. Acta Biochim Pol 2002, 49:877-889.

15. Czajkowski R, Banachewicz W, Ilnytska O, Drobot LB, Baranska J: Differential effects of $P 2 Y I$ and $P 2 Y I 2$ nucleotide receptors on ERKI/ERK2 and phosphatidylinositol 3-kinase signalling and cell proliferation in serum-deprived and nonstarved glioma C6 cells. BrJ Pharmacol 2004, I 41:497-507.

16. Baranska J, Czajkowski R, Sabala P: Cross-talks between nucleotide receptor-induced signalling pathways in serumdeprived and non-starved glioma C6 cells. Adv Enzyme Regul 2004, 44:219-232.

17. Morrone FB, Jacques-Silva MC, Horn AP, Bernardi A, Schwartsmann G, Rodnight R, Lenz G: Extracellular nucleotides and nucleosides induce proliferation and increase nucleoside transport in human glioma cell lines. J Neuroncol 2003, 64:21I-218.

18. Morrone FB, Horn AP, Stella J, Spiller F, Salbego C, Lenz G, Battastini AMO: Increased resistance of glioma cell lines to extracellular ATP cytotoxicity. J Neuroncol 2005, $7 \mathrm{I}: 135-140$.

19. Wink MR, Lenz G, Braganhol E, Tamajusuku AS, Schwartsmann G, Sarkis JJ, Battastini AMO: Altered extracellular ATP, ADP and AMP catabolism in glioma cell lines. Cancer Lett 2003, 198:211-218.

20. Neary JT, Kang Y, Tran M, Feld J: Traumatic injury activates protein kinase B/Akt in cultured astrocytes: role of extracellular ATP and P2 purinergic receptors. I Neurotrauma 2005, 22(4):49I-500.

21. Patel VJ, Elion GB, Houghton PJ, Keir S, Pegg AE, Johnson SP, Dolan $M E$, Bigner DD, Friedman HS: Schedule-dependent activity of temozolomide plus CPT-I I against a human central nervous system tumor-derived xenograft. Clin Cancer Res 2000, 6:4154-4I57.

22. Chan $K$, Delfert $D$, Junger $K D$ : A direct colorimetric assay for $\mathrm{Ca}^{2+}$-ATPase activity. Anal Biochem 1986, I57:375-80.

23. Zerbini LF, Wang Y, Cho JY, Libermann TA: Constitutive activation of nuclear factor $\mathrm{kB}$ p50/p65 and Fra- $I$ and junD is essential for deregulated interleukin 6 expression in prostate cancer. Cancer Res 2003, 63:2206-2215.

24. Vollmayer P, Koch M, Braun N, Heine P, Servos J, Israr E, Kegel B, Zimmermann $\mathrm{H}$ : Multiple ecto-nucleotidases in PCI 2 cells: identification and cellular distribution after heterologous expression. J Neurochem 200I, 78(5): 1019-1028.

25. Newlands ES, Foster T, Zaknoen S: Phase I study of temozolamide (TMZ) combined with procarbazine (PCB) in patients with gliomas. Br J Cancer 2003, 89(2):248-25I.

26. Zimmermann H: Ectonucleotidases: Some recent developments and note on nomenclature. Drug Dev Res 200I, 52:44-56.

27. Shi JD, Kukar T, Wang CY, Li QZ, Cruz PE, Davoodi-Semiromi A, Yang P, Gu Y, Lian W, Wu DH, She JX: Molecular cloning and characterization of a novel mammalian endo-apyrase (LALPI). J Biol Chem 200I, 276:7474-17478.

28. Bigonnesse F, Lévesque AS, Kukulski F, Lecka J, Robson SC, Fernandes MJG, Sévigny J: Cloning and Characterization of Mouse Nucleoside Triphosphate Diphosphohydrolase-8. Biochemistry 2004, 43:55II-55। 9 .

29. Dzhandzugazyan KN, Kirkin AF, thor Straten P, Zeuthen J: EctoATP diphsophohydrolase/CD39 is over expressed in differentiated human melanomas. FEBS Let 1998, 430:227-230.

30. Knowles FA: Inhibition of growth and induction of enzyme activities in a clonal human hepatoma cell line (Li7A): comparison on the effects of epidermal growth factor and an anti-epidermal growth factor receptor antibody. J Cell Physiol 1988, 134:109-116. 
31. Knowles AF: Differential expression of ecto-Mge+-ATPase and ecto-Ca ${ }^{2+}$-AtPase activities in human hepatoma cells. Arch Biochem Biophys 1988, 263:264-27I.

32. Paez JG, Recio JA, Rouzaut A, Notario V: Identity between the PCPH proto-oncogene and the CD39L4 (ENTPD5) ectonucleoside triphosphate diphosphohydrolase gene. Int J Onco 200I, 19:1249-1254.

33. Amadio S, D'Ambrosi N, Cavaliere F, Murra B, Sancesario G, Bernardi G, Burnstock G, Volonté C: $\mathbf{P 2}$ receptor modulation and cytotoxic function in cultured CNS neurons. Neuropharmacol 2002, 42:489-50I.

34. Heine $P$, Braun N, Heilbronn A, Zimmermann $\mathrm{H}$ : Functional characterization of rat ecto-ATPase and ecto-ATP diphosphohydrolase after heterologous expression in $\mathrm{CHO}$ cells. Eur J Biochem 1999, 262(I): 102-107.

35. Auguste $P$, Gürsel $D B$, Lemière $S$, Reimers $D$, Cuevas $P$, Carceller $F$, Di Santo JP, Bikfalvi A: Inhibition of fibroblast growth factorl fibroblast growth factor receptor activity in glioma cells impedes tumor growth by both angiogenesis-dependent and-independent mechanisms. Cancer Res 200I, 61:1717-1726.

36. Merighi S, Benini A, Mirandola P, Gessi S, Varani K, Leung E, Maclennan S, Borea PA: Adenosine modulates vascular endothelial growth factor expression via hypoxia-inducible factor- $I$ in human glioblastoma cells. Biochem Pharmacol 2006, 72(I):|9-31.

\section{Pre-publication history}

The pre-publication history for this paper can be accessed here:

http://www.biomedcentral.com/1471-2407/6/226/pre pub

Publish with Bio Med Central and every scientist can read your work free of charge

"BioMed Central will be the most significant development for disseminating the results of biomedical research in our lifetime."

Sir Paul Nurse, Cancer Research UK

Your research papers will be:

- available free of charge to the entire biomedical community

- peer reviewed and published immediately upon acceptance

- cited in PubMed and archived on PubMed Central

- yours - you keep the copyright

Submit your manuscript here:

http://www.biomedcentral.com/info/publishing_adv.asp 